\title{
KEMAJUAN SAINS DAN PENYELIDIKAN DI NEGERI-NEGERI SELAT DAN NEGERI-NEGERI MELAYU BERSEKUTU, 1800-1941
}

\author{
Sawi Linus Sungat
}

\begin{abstract}
This article examines the historical context in which scientific research institutions were established in the Straits Settlements and the Malay States between 1800 and the Japanese Occupation. It cannot be denied that one of the main impetus in the development of both the Straits Settlements as well as the Federated Malay States was the progress made in science and scientific research. The article focuses on two parts, namely, British education policy in regard to science; and secondly, the establishment of scientific research institutions for socio-economic reasons. The development of scientific knowledge and skills in schools and other educational institutions as well as the establishment of scientific research institutions pointed to British interest in wanting to consolidate their colonial interest in Malaya in the late 19th and early 20th century. It was these educational and research institutions which provided the requisite technical know-how that was necessary for the effective administration of the country, for the development of primary economic resources and the control of diseases affecting migrant labour.
\end{abstract}

\section{Pengenalan}

Profesor Dr. Awang Had Salleh dalam artikelnya bertajuk “Teknologi Dalam Pendidikan” mendefinisikan sains sebagai himpunan pengetahuan atau ilmu yang telah diuji yang dapat dinyatakan dalam bentuk set prinsip-prinsip am. ${ }^{1}$ Philip A. Cogin dalam bukunya Technology and Man menyatakan bahawa sains boleh dibahagikan kepada dua makna. Dalam perkataan biasa, ia adalah pengetahuan dan dalam pengertian yang lebih terbatas lagi sains adalah ilmu pengetahuan yang boleh diuji dengan mengadakan uji kaji. ${ }^{2}$ Sybil P. Paker pula menyatakan bahawa sains berdasarkan kepada kemungkinan dalam membuat kenyataan khusus yang memerlukan pengujian dan dalil-dalil yang nyata. ${ }^{3}$ James R. Newman menyatakan sains sebagai badan penyusun mengenai pengetahuan dan pendapat yang memerlukan sokongan sistematikdari bukti-bukti yang nyata atau kenyataan yang dibuat melalui pemerhatian. ${ }^{4}$ Menurut Pusat Rujukan Persuratan Melayu, ${ }^{5}$ institusi sains dapat ditakrifkan sebagai badan yang melaksanakan tugas mengatur dan mengurus ilmu yang boleh diuji dengan mengadakan uji kaji. Dalam konteks Negeri-negeri Selat dan NNMB ia merujuk kepada institusi yang menjalankan tugas-tugas khusus bagi menyelesaikan masalah sosioekonomi ketika itu.

Teknologi pula adalah pengetahuan dan perlakuan yang sistematik, kebiasaannya adalah industri tetapi ia juga dapat digunakan untuk aktiviti-aktiviti yang berulang-ulang. Teknologi mempunyai hubungan yang rapat dengan sains dan kejuruteraan. Sains lebih banyak menumpukan kepada soal kemanusiaan yang memahami tentang alam nyata yang berkaitan dengan kejuruteraan. ${ }^{6}$ David Dickson pula mendefinisikan teknologi sebagai satu konsep abstrak yang merangkumi peralatan dan mesin yang digunakan oleh masyarakat. ${ }^{7}$ William F. Cottrell pula manyatakan bahawa teknologi adalah pengetahuan tentang kemahiran menggunakan peralatan mesin. ${ }^{8}$ Secara keseluruhan, teknologi adalah aplikasi ataupun pemindahan kreatif sains kepada keperluan industri atau apa-apa keperluan praktikal yang lain. ${ }^{9}$ Kebiasaan, penghuraian dan istilah-istilah berkenaan dengan sesuatu atau semua tentang sains gunaan yang mana mempunyai nilai yang berguna dan untuk kegunaan industri. ${ }^{10}$ 
Berdasarkan takrifan di atas tidak dapat dinafikan bahawa terdapat hubungan rapat antara sains dan teknologi. Oleh kerana itu membincangkan sains ataupun teknologi secara bersendirian kurang sesuai. Ini kerana ikatan kedua bidang ilmu tersebut amat rapat walaupun pada kenyataannya ia merupakan disiplin ilmu yang berbeza. Dari segi hubungan antara keduanya didapati bahawa sains adalah pengajaran pengetahuan serta pemahaman tentang alam sekitar fizikal dan manusia sementara teknologi pula adalah hubungan pengetahuan berdasarkan teori khusus untuk tujuan sosial dan ekonomi serta mempunyai tanggungjawab yang besar untuk menyempurnakannya. ${ }^{11}$

Pendidikan vokasional dapat didefinisikan sebagai pendidikan yang membolehkan seseorang itu menjalankan atau membuat beberapa pekerjaan tertentu. Menerusi pendidikan, kanak-kanak yang meninggalkan alam persekolahan dapat diberi asas kemahiran yang membolehkan mereka membuat sesuatu pekerjaan. Matlamat pendidikan vokasional adalah luas. Ia tidak terhad hanya kepada latihan untuk jenis pekerjaan kolar biru sahaja tetapi merangkumi juga pekerjaan yang memerlukan tugas pelaksanaan dan penyeliaan ke atas projek-projek tertentu. Umumnya ada empat tahap pekerjaan mengikut pemeringkatan pendidikan vokasional. Tahap pertama, tahap separa mahir, berupa latihan jangka pendek yang diberi untuk kemahiran-kemahiran asas seperti di bidang membuat batu bata, motor mekanik dan lain-lain. Tahap kedua merupakan latihan operatif, yang memberi latihan selama dua tahun atau lebih dan bertujuan mengeluarkan pekerja dalam kategori juruteknik, pembantu ladang dan lain-lain. Tahap ketiga ialah tahap separa iktisas yang mengeluarkan pegawai peringkat pertengahan. Pegawai-pegawai ini selalunya telah menerima pendidikan tinggi dan memperoleh diploma atau kelulusan-kelulusan asas yang lain. Tahap keempat ialah tahap profesional yang berupa latihan kepada mereka yang mempunyai kelulusan ijazah dan profesional. ${ }^{12}$ Biasanya mereka memegang jawatan-jawatan tinggi sebagai pengurus, perancang dan pekerjaan lain. ${ }^{13}$

The United Nations Educational, Scientific and Cultural Organisation (UNESCO) mentakrifkan pendidikan teknik dan vokasional seperti berikut:

Pendidikan teknikal dan vokasional sebagai aspek proses pendidikan yang melibatkan, selain pendidikan am, pembelajaran tentang teknologi dan sains yang berkaitan, serta pemerolehan kemahiran praktikal, sikap, pemahaman dan ilmu yang berkaitan dengan pekerjaan dalam pelbagai sektor ekonomi dan kehidupan sosial. ${ }^{14}$

\section{Matlamat British Menubuhkan Institusi Sains}

Sebelum kedatangan British orang Melayu telah belajar dalam jurusan teknik dan vokasional, tetapi mengikut cara tradisi turun-temurun. Kemahiran tersebut adalah seperti ilmu ukiran, pengetahuan membuat bakul, pertukangan besi, membuat azimat dan kerisyang diajar oleh seorang guru mahir dan terkenal. ${ }^{15}$ Namun keperluan menubuhkan institusi sains hanya dapat diperhatikan di Negeri-negeri Selat selepas penguasaan Pulau Pinang oleh Francis Light pada 1786. Keperluantersebutbertambah lagi dengan penubuhan Negeri-negeri Selat pada 1826 dan perkembangan pesat perdagangan ketiga-tiga penempatan ini (Pulau Pinang, Melaka dan Singapura). Dalam keadaan ini tidak hairan mengapa institusi sains perlu diberi penekanan untuk melahirkan golongan cerdik pandai bagi mentadbir perkhidmatan awam penempatan ini dan juga untuk melahirkan pekerja mahir bagi memaju pembangunan Negeri-negeri Selat. Di negeri-negeri Melayu pula keperluan ini menjadi nyata selepasa campurtangan British secara rasmi pada 1874 dan sesudah penubuhan Persekutuan pada 1896. Persekutuan telah menyatukan keempat-empat Negeri-negeri Melayu Bersekutu (Perak, Selangor, Negeri Sembilan dan Pahang) di bawah satu persekutuan yang menyaksikan keseragaman dalam 
pentadbiran dan dalam bidang-bidang lain. Sejak Persekutuan dilaksanakan dari 1 Julai 1896 sehingga penubuhan Majlis Mesyuarat Persekutuan pada 1909, Persekutuan telah mengambil langkah-langkah yang perlu dari segi pentadbiran, ekonomi dan sosial untuk menggalakkan pelaburan. Kepesatan ekonomi yang dialami oleh Negeri-negeri Melayu Bersekutu memang disumbangkan oleh institusi sains penyelidikan seperti Institusi Penyelidikan Hutan, Institut Penyelidikan Getah dan Institut Penyelidikan Perubatan.

\section{Penubuhan Institusi Sains di Negeri-negeri Selat}

Usaha untuk menubuhkan institusi sains yang memberi penekanan kepada kemahiran teknikal bermula pada 1816 apabila Rev. R.S. Hutchings mengasaskan Penang Free School. ${ }^{16}$ Institusi ini menetapkan bahawa pada usia tertentu murid akan diajar mata pelajaran yang berguna untuk menjadi tukang kayu, tukang besi, tukang kasut, tukang jahit dan penjilid buku. ${ }^{17}$

Keperluan untuk memberi penekanan kepada kemahiran teknikal terserlah lagi apabila Stamford Raffles sebagai Lieuteran-Gabenor Bangkahulu memajukan Singapura sebagai pelabuhan bebas. Beliau telah mengesyorkan penubuhan sekolah bagi anak-anak bumiputera pada 1820 dan telah mengesyorkan sekolah perusahaan. ${ }^{18}$ Namun menurut seorang sarjana yang mengkaji tentang hal ini iaitu D.D. Chelliah, berpendapat tidak wujud sebarang bukti yang menunjukkan bahawa British bertindak pada syor ini.

Di Singapura, seorang warganegara Amerika iaitu William Keasberry ${ }^{19}$ telah memajukan sebuah sekolah berasrama iaitu sebuah sekolah percetakan dan seni tulisan khas bagi kanak-kanak lelaki Melayu yang dibuka di Kampung Glam sekitar tahun tahun $1848 .{ }^{20}$ E.A. Blundell, Gabenor Negeri-negeri Selat, telah tertarik hati dengan kejayaan tersebut dan mengesyorkannya dijadikan sebagai contoh bagi penubuhan institusi lain. Walau bagaimanapun, Woolley Committee yang ditubuhkan pada tahun 1870 untuk menyelidik pelajaran di Negeri-negeri Selat telah memberikan laporan yang menentang penubuhan sekolah perusahaan. ${ }^{21}$ Sebenarnya terdapat kaitan antara sekolah perusahaan dengan percetakan kerana ia juga merupakan satu perniagaan atau industri yang berkaitan dengan kemahiran(percetakan, penjilidan buku dan litografi). ${ }^{22}$ Selain itu kejayaan sekolah yang ditubuhkan oleh Keasberry ${ }^{23}$ telah memberikan inspirasi kepada penubuhan institusi lainselepas itu. Walau bagaimanapun oleh kerana terdapat tentangan daripada Woolley Committee, sekolah yang diwujudkan oleh Keasberry telah ditutup pada tahun 1875 setelah beliau meninggal dunia.

Pada tahun 1902, Kynnersley Commission telah dilantik untuk menyelidik sistem pelajaran di tanah jajahan terutama mengenai pelajaran sekolah menengah dan teknik. Suruhanjaya tersebut telah mengemukakan laporan bahawa tidak cukup syarat untuk membolehkan penubuhan institusi teknik yang berasingan di Singapura dan tidak cukup syarat untuk menubuhkan institut teknik di setiap Negeri-negeri Selat. Walau bagaimanapun suruhanjaya tersebut telah mencadangkan supaya kerajaan British mengambil alih Institusi Raffles di Singapura dan Penang Free School dimana pelajaran teknik dan perdagangan boleh diperluaskan secara beransur-ansur apabila perlu. ${ }^{24}$

Jawatankuasa Winstedt berkenaan Pelajaran Perusahaan dan Teknik yang dibentuk pada tahun 1925 merupakan satulagi bukti bahawa kerajaan mengambil berat untuk memajukan latihan vokasional. Jawatankuasa ini melaporkan pelajaran perusahaan dan teknik perlu diadakan di Singapura. ${ }^{25}$ Jawatankuasa itu kemudiannya mencadangkan jenis-jenis kelas dan pengajaran yang sesuai di pulau itu terutama sekali keperluan kerani-kerani yang boleh bertutur bahasa Inggeris, pembantu-pembantu pengukur, mandur-mandur jalan dan jurutera-jurutera laut; keperluan bagi latihan-latihan yang sesuai untuk bakal-bakal mekanik di sekolah-sekolah perdagangan; perlantikan Ketua Nazir Pelajaran Perdagangan untuk mengadakan dan menyelia kelas-kelas dalam bahasa Inggeris dan sekolah-sekolah vernakular 
(kerajaan dan bantuan) untuk mengajar ilmu-ilmu perdagangan yang mudah seperti pertukangan. ${ }^{26}$

Untuk mengurangkan kos (dari segi upah yang mahal) dan kesedaran pentingnya keperluan tenaga kerja mahir dapat dipenuhi oleh tenaga tempatan tanpa terlalu bergantung dengan tenaga asing seperti orang Eropah, makaBritish telah menubuhkan dua institusi yang sangat penting peranannya dari segi ekonomi dan sosial terhadap Singapura dan juga bagi Tanah Melayu. Atas alasan tersebut maka telah diwujudkan institusi berikut:

\section{a. Maktab Perubatan King Edward}

Pada tahun 1904, Encik Tan Jiak Kim merayu kepada Gabenor Sir John Anderson supaya ditubuhkan sekolah perubatan.Ordinan No. XV, 1905, ${ }^{27}$ telah merealisasikan penubuhan sebuah maktab perubatan di Tanah Melayu dengan nama asalnya "The Straits and Federated Malay States Government Medical School.”28 Pada tahun 1916, diploma maktab ini telah diiktiraf oleh General Medical Council Great Britain.Maktab ini setaraf dengan maktabmaktab perubatan di Britain. Maktab ini melatih pelajar dalam pengajian perubatan, pembedahan dan perbidanan (kursus 5 tahun) dan pembantu hospital (kursus 2 tahun). Maktab ini mampu menyediakan prasarana dan tenaga pengajar dalam bidang Kimia dan Fizik, Biologi, Biokimia, Anatomi, Fisiologi, Bakteriologi, Patologi, Farmaseutikal, Kesihatan Awam, Jurispruidens Perubatan dan Toksikologi, Perubatan Surgeri, Perbidanan dan Ginekologi serta Pergigian.

\section{b. Kolej Raffles}

Raffles College atau Maktab Raffles juga adalah antara institusi awal yang memperkenalkan mata pelajaran sains. Institusi ini telah ditubuhkan pada 22 Julai $1929^{29}$ dan mata pelajaran sains yang terdapat dalam kurikulum kolej berkenaan ialah Kimia dan Fizik. Raffles College mempunyai peralatan untuk mengajar mata pelajaran Kimia dan Fizik hingga ke peringkat School Certificate.

Kolej ini berobjektif untuk memberi penekanan khusus kepada pendidikan seni dan sosial sains di tahap tertiari kepada penuntut Melayu. Terdapat dua aliran penting iaitu seni dan sains sosial. Empat tahun kemudian, Majlis Kolej telah menyarankan perubahan terhadap kurikulum akademiknya, dimana pemerkayaan kursus yang ditawarkan diberikan Ijazah Diploma supaya kemudian pelajar dapat melanjutkkan pelajaran keperingkat Ijazah Sarjana Muda dan Ijazah Sarjana Tinggi melalui suatu bentuk peperiksaan khusus dengan kerjasama universiti-universiti di England. Apabila Kolej Raffles tertubuh, maka guru-guru pun diberi latihan di sini. Sesudah merdeka, kebanyakan pegawai pelajaran terdiri dari graduan sastera atau sains dari Kolej Raffles. ${ }^{30}$

\section{Penubuhan Institusi Sains di Negeri-negeri Melayu Bersekutu}

Pengenalan institusi sains di Tanah Melayu dapat diperhatikan dengan pengenalan pelajaran teknik. Penubuhan institusi pengajian teknikal pada zaman penjajahan British, biarpun konsepnya tidak dicernakan dengan sempurna dan dirancang dengan rapi, namun ia mempunyai kaitan yang signifikan dengan perkembangan ekonomi Tanah Melayu ketika itu. $^{31}$ Berikutan pembangunan infrastruktur yang pesat, British memerlukan pakar teknikal yang terlatih dalam pelbagai bidang profesional. Penubuhan beberapa sekolah teknikal pada awal abad ke-20 yang diletakkan di bawah beberapa jabatan pentadbiran telah merintis jalan kepada penubuhan institusi pendidikan teknikal yang kukuh.

Pada peringkat awal, pendidikan teknikal tidak mendapat perhatian yang sewajarnya daripada pihak pentadbiran British sekalipun idea penubuhannya digagaskan oleh mereka. Namun perkembangan yang berlaku dalam kegiatan ekonomi terutama yang berkaitan dengan aktiviti perlombongan bijih timah dan perladangan getah menyebabkan sektor lain 
turut menerima tempiasnya. ${ }^{32}$ Perkembangan infrastruktur seperti jalan raya, jalan kereta api, telegraf, telekomunikasi, elektrik dan sebagainya menyebabkan wujud keperluan dan permintaan guna tenaga. Ini mendorong pihak British memberikan perhatian dalam menyediakan tenaga pekerja teknikal yang terlatih dan profesional. Laporan pendidikan British pada tahun 1899 banyak membincangkan keperluan menyediakan pendidikan teknikal, perdagangan dan jawatan profesional yang lain.

Penubuhan beberapa sekolah teknikal pada awal abad ke-20 yang diletakkan di bawah beberapa jabatan pentadbiran telah merintis jalan kepada penubuhan institusi pendidikan teknikal yang kukuh. Perkhidmatan perkeranian dan perdagangan terbukti menjadi bidang yang sangat penting untuk kegiatan pekerjaan dan pembangunan ekonomi Tanah Melayu. Namun, oleh sebab kemelesetan ekonomi yang diakibatkan oleh Perang Dunia Pertama, maka kemasukan pelajar ke sekolah teknik terganggu.

\section{Rasional British Memperkenalkan Institusi Sains}

Tuntutan zaman yang semakin berkembang pesat sudah tentu menuntut keperluan modal insan yang mempunyai kemahiran dalam bidang-bidang tertentu. Atas alasan tersebut British telah memperkenalkan pendidikan sains di tanah jajahan mereka termasuklah Tanah Melayu. Tujuan sebenar British memperkenalkan pendidikan teknik di Tanah Melayu adalah untuk mengeluarkan pegawai-pegawai teknik rendah. Walau bagaimanapun pada awalnya matlamat ini tidak mendapat sambutan dalam kalangan pelajar tempatan yang berkelayakan kerana lebih tertarik bekerja di pejabat-pejabat sebagai kerani kerana upah yang lebih lumayan. Atas penilaian terhadap matlamat tersebut Winstedt mengatakan bahawa "except as asurvey it was not a success." ${ }^{33}$ Perkembangan pendidikan sains dapat dikesan daripada beberapa laporan yang telah disediakan oleh British untuk meninjau kepentingan sains.

\section{Peringkat Sekolah dan Pengajian Tinggi \\ a. Melahirkan Tenaga Kerja Mahir}

British mewujudkan pendidikan sains di Tanah Melayu untuk melahirkan tenaga kerja mahir. Hal ini dapat dilihat dengan penubuhan beberapa jawatankuasa yang dapat membantu mencapai matlamat tersebut.

\section{Laporan Pendidikan British, 1899}

Kepentingan pengajian teknikal dapat dilihat melalui laporan pendidikan British yang dikeluarkan pada tahun 1899 yang banyak membincangkan mengenai keperluan menyediakan pendidikan teknikal, perdagangan dan jawatan profesional lain. Sungguhpun demikian, idea dan cadangan ini sukar dilaksanakan kerana ketiadaan peruntukan kewangan yang dikhususkan untuk pendidikan profesional. Namun begitu, beberapa usaha telah diambil untuk mengisi keperluan tenaga profesional menerusi kegiatan 'perantisan' oleh Jabatan Kerja Raya dan Jabatan Ukur serta beberapa institusi persendirian, yang sedikit sebanyak dapat mengatasi masalah ini. ${ }^{34}$

\section{Jawatankuasa Winstedt, 1925}

Jawatankuasa Winstedt telah dibentuk pada tahun 1925 untuk memberi cadangan pembaikan tentang pelaksanaan pendidikan teknikal dan industri. Cadangan Jawatankuasa Winstedt ialah:

i. Pendidikan Teknikal Tinggi yang dibiayai kerajaan perlu dilaksanakan hingga ke peringkat ijazah sarjana muda bagi membolehkan negara memperoleh staf yang berkelayakan dalam bidang kejuruteraan, ukur dan seni bina. Cawangan kejuruteraan dari Kolej Raffles juga perlu dirujuk untuk mendapat pengiktirafan. 
ii. Melaksanakan Pendidikan Teknikal Pertengahan yang menggunakan bahasa Inggeris sebagai bahasa pengantar untuk Kerani Kerja Raya, Pembantu Ukur, Juruteknik Jalan dan Bangunan, Jurutera Kapal, Seni Bina dan Pelukis Pelan. Permintaan ke atas jenis pendidikan ini juga dilaksanakan untuk sesi kelas petang atau malam. ${ }^{35}$

\section{Laporan Pendidikan Vokasional di Tanah Melayu, 1939}

Report on Vocational Education in Malayapada $1939^{36}$ telah membincangkan mengenai kurangnya kemudahan bagi pengajaran mata pelajaran sains di sekolah Inggeris di Tanah Melayu. Dalam laporan itu juga telah dibincangkan perlunya satu sukatanpelajaran bagi mata pelajaran sains. Selain itu satu jawatankuasa ditubuhkan bagi mengkaji masalah ini dengan lebih teliti. Akhirnya satu keputusan telah diambil iaitu mata pelajaran sains perlu diajar di sekolah.

Our terms of reference do not require us to state whether we consider science should be in the curriculum of all schools, though the appointment of the committee might imply that this has been recognized. We had however to come to a decision as to the extent of the science teaching before we could consider the aims. ${ }^{37}$

British berpendapat mereka perlu memasukkan mata pelajaran sains sebagai sebahagian daripada kurikulum di sekolah menengah.Pentadbir British berpendapat mata pelajaran sains perlu dilaksanakan di Tanah Melayu dengan membuat beberapa perubahan. W.G.A. Ormsby Gore (Heads of English School in Malaya) yang melawat Malaya berpendapat sains perlu diperkenalkan di Tanah Melayu kerana beberapa sebab:

In the modern world a purely literary education can no longer be described as general Education. Scientific discovery is playing so large a part in our lives today that no education can be called a general education that does not give that answer "how" and "why" regarding so many things which we regard as the accompanimentsof civilization. The task of science is after all the search for truth. It aims at understanding the processes and laws of the universe, and on the basis of that understanding, at harnessing the forces of nature to man's use and well-being. It must not be regarded as the alternative, still less the opposition, to the teaching of "humanities". But it is the necessary compliment. No system of education which neglects modern Sciencecan be said to be either balanced or complete. ${ }^{38}$

Kenyataan ini telah menyebabkan mata pelajaran sains diperkenalkan dalam sistem pendidikan British.Tujuan British memperkenalkan mata pelajaran sains di sekolah-sekolah di Tanah Melayu ialah untuk menambahkan tenaga pekerja yang berkelulusan sekolah Inggeris dan berpengetahuan luas. Memandangkan Sijil Cambridge menjadi ujian wajib bagi mendapatkan kerja sama ada di sektor kerajaan mahupun swasta adalah adil jika murid-murid yang mahir dalam sains diberi peluang dalam peperiksaan ini.

Pelaksanaan mata pelajaran sains amat berkesan kepada murid-murid tempatan. Mata pelajaran sains memberi pengetahuan mengenai hukum semula jadi. Murid-murid mengetahui fungsi alam semesta dan aplikasinya. Sains juga memberi pengenalan mengenai 
kaedah sains kepada kanak-kanak. Walaupun begitu, sains tidak menarik minat kesemua murid tempatan.

\section{b. Kemahiran Teknikal}

British memajukan pendidikan sains di Tanah Melayu juga dengan tujuan untuk membawa kemahiran teknikal. Hal ini dapat dibuktikan dengan melihat beberapa jawatankuasa yang menyokong hal tersebut seperti berikut:

\section{Laporan Messrs, Coales, Watson dan Worley, 1927}

Pada tahun 1927, satu laporan telah dikemukakan oleh Messrs, Coales, Watson dan Worley agar sekolah teknik disatukan bagi melatih pekerja teknikal bukan sahaja untuk jabatan kerajaan tetapi juga terbuka untuk pihak swasta. ${ }^{39}$ Cadangan ini telah diterima dan diluluskan, walau bagaimanapun masalah kewangan sekali lagi menyebabkan pelaksanaan rancangan ini ditangguhkan. ${ }^{40}$

\section{Laporan The Teaching of General Science ${ }^{41}$}

Laporan The Teaching of General Science ${ }^{42}$ menyatakan bahawa tujuan mata pelajaran sains diperkenalkan di sekolah adalah untuk memenuhi maklumat berikut:

In one way especially the teaching of science will benefit the community. A state will best function when the intellectual climate in which its member live is suited the tasks they perform. Scientists and inventors do better work when their efforts do not meet blind opposition and when the spirit of the times is in sympathy with them. We should therefore give our pupils some notion of many ways in which science enters our lives and has influenced and altered our occupation. ${ }^{43}$

Mata pelajaran sains diajar di sekolah menengah sebagai langkah pertama menyediakan murid ke alam pekerjaan yang lebih saintifik dan teknikal.Walaupun demikian tujuan utama British memperkenalkan sains bukan hanya sebagai persediaan untuk pekerjaan tetapi juga untuk menyediakan individu menghadapi zaman sains. Menurut Butcher:

It was to be planned as a self contained whole, designed as a preparation for life in a scientific age rather than as a mere preparation for examination or for scientific career. ${ }^{44}$

Mata pelajaran sains bukan hanya menyediakan murid untuk peperiksaan tetapi juga untuk kegunaan harian.Sebab itulah topikPublic Health telah diselitkan dalam sukatan pelajaran sains. Walaupun sebelum ini mata pelajaran Hygienesudah dimulakan namun pelaksanaan sains telah membawa kesan yang lebih baik dan efektif. Usaha kerajaan British memperkenalkan mata pelajaran sains telah melahirkan ramai doktor dan ramai profesional dengan kelayakan teknikal. Dasar anak seorang petani menjadi petani yang lebih baik dari bapanya tidak lagi wujud. Ini kerana seorang yang ingin meningkatkan pengetahuan boleh berbuat demikian jika dia mampu dan mendapat pekerjaan yang lebih baik dari bapanya. ${ }^{45}$

Walaupun pada awalnya objektif British memperkenalkan dasar pendidikan baru adalah amat terhad, namun kenyataan yang dikeluarkan oleh Pengarah Pendidikan pada tahun 1923 yang tertera di bawah telah mengubah dasar pendidikan British. Menurut beliau: 
With the spread of English education, knowledge of that language will cease to be an open sesame to fortune or even to a livelihood, and one of the gravest problem today is to devise for the coming generation types of instructions fitting the young of Malaya for such careers as the country offers. There can be no doubt that the bulk of the inhabitants must turn to agriculture and other industries, and that the Education Department will have to equip them for those paths of life. Any ideal of education, not adjusted to local wants, must lead to economic dislocation and social unrest. ${ }^{46}$

Kenyataan di atas jelas membuktikan bahawa British sedar kepentingan institusi sains bagi kemajuan sosioekonomi. Murid-murid yang berpengetahuan sains juga boleh menggunakan pengetahuan mereka dalam kehidupan seharian.Pengetahuan sains membantu pelajar melakukan tugas harian mereka dengan lancar dan sempurna. Ini dinyatakan dalam Regulation for Malay Vernacular Education:

Knowledge of Biology, for example, can help towards more rational and healthy living. This subject forms the best foundation for a study of the laws of hygiene and an appreciation of the data underlying practical hygiene advice mayfacilitate its rapid adoption. ${ }^{47}$

Kerajaan British menghadapi masalah dalam melaksanakan mata pelajaran sains dalam sistem pendidikan di Tanah Melayu. Namun tujuan kerajaan British adalah untuk menambahkan tenaga pekerja yang berkelulusan tinggi. Oleh itu banyak jawatankuasa ditubuhkan untuk melakukan perubahan yang sewajarnya.Mata pelajaran sains pada awalnya diperkenalkan di sekolah-sekolah Inggeris. Semua peralatan sains disediakan untuk sekolah Inggeris. Dalam laporan Teaching of General Science dinyatakan bahawa mata pelajaran sains harus dijadikan sebahagian daripada kurikulum secepat mungkin. Adalah dipercayai murid-murid dalam lingkungan umur 11-16 tahun mempunyai sikap ingin tahu yang kuat. Selain itu, minat murid-murid juga kerap bertukar dalam lingkungan umur ini. Laporan ini mencadangkan supaya sikap ingin tahu murid digunakan dengan cara yang positif. ${ }^{48}$

General science should therefore be a course of scientific study and investigation which has its roots in the common experience of children and does not exlude any of fundamental sciences. It seeks to elucidate the general principles observable in nature, without emphasising the traditional division into specialised subjects until such time as this is warranted by the increasing complexity of the field of investigation, by developing unity of the separate parts of that field and by the intellectual progress of the pupils. ${ }^{49}$

\section{Consultative Committee on Secondary Education, 1941}

Kepentingan mata pelajaran sains telah membawa kepada penubuhan satu jawatankuasa bernama 'Consultative Committee On Secondary Education' pada 1941. ${ }^{50}$ Jawatankuasa ini dilantik bagi mengkaji tujuan pengajaran mata pelajaran sains di sekolah. Laporan yang disediakanolehjawatankuasa ini telah diterima sebulat suara oleh ahli-ahlinya. Laporan ini telah memutuskan bahawa mata pelajaran sains akan diajar di Tanah Melayu di peringkat 
sekolah. Laporan ini juga mengesyorkan beberapa tujuan yang menyebabkan keputusan ini diambil. Antaranya ialah:

1. Mata pelajaran sains memberi pengetahuan kepada murid mengenai hukum alam yang menjana alam semesta dan aplikasi hukum alam. Ia bertujuan untuk mengetahui kegunaan alam semesta.

2. Mata pelajaran sains mendedahkan pencapaian dalam perkembangan tamadun secara saintifik.

3. Sains diperkenalkan supaya murid-murid mendapat pendedahan saintifik. ${ }^{51}$

\section{c. Melahirkan Golongan Berkemahiran Pertanian}

Matlamat British melahirkan golongan yang berkemahiran pertanian dapat dibuktikan melalui penubuhan jawatankuasa berikut:

\section{Jawatankuasa Kynnersley, 1902}

Suruhanjaya Kynnersley ditubuhkan pada tahun 1902 untuk membincangkan penubuhan sistem persekolahan Inggeris dan pendidikan sekolah menengah di Tanah Melayu. Melalui suruhanjaya ini dibincangkan penubuhan institusi pendidikan teknikal dan pelaksanaannya secara komersial. Setiausaha Malay Agriculture Settlement telah menghantar surat kepada Residen Selangor pada tahun 1902 dan menyatakan bahawa beliau bersetuju memberi peruntukan tambahan sebanyak \$500, sebagai tambahan peruntukan berjumlah $\$ 6000$ untuk tujuan perbelanjaan perkhidmatan, pertanian orang Melayu dan Sekolah Teknik. ${ }^{52}$ Walau bagaimanapun kekurangan sumber kewangan telah membantutkan usaha menubuhkan Sekolah Teknik ketika itu. Atas sebab kekangan ini, setiap jabatan yang ada seperti Jabatan Ukur, Jabatan Kerja Raya, Jabatan Keretapi dan Jabatan Pertanian terpaksa mengambil ikhtiar sendiri untuk mengeluarkan tenaga kerja berpengetahuan dan mahir dalam bidang teknikal mengikut keperluan organisasi masing-masing. ${ }^{53}$

\section{d. Sains Menjadi Lebih Terbuka}

British juga memperkenalkan mata pelajaran sains agar ia menjadi lebih terbuka khususnya kepada masyarakat tempatan. Sains tidak lagi hanya dipelajari oleh orang Eropah juga akan diajar kepada semua golongan. Hal ini dapat dilihat melalui penubuhan jawatankuasa seperti berikut:

\section{Laporan Suruhanjaya Lemon, 1918}

Pada awal abad ke-20 telah timbul kesedaran dalam kalangan pentadbir British untuk menyemak keperluan mengadakan pendidikan teknik dan perusahaan di NNM. Ini amat perlu kerana pertumbuhan ekonomi perlombongan dan getah memerlukan tenaga buruh yang berkemahiran dalam teknikal dan perusahaan untuk menyumbang kepada sektor ekonomi ini. Ini menyebabkan pada tahun 1918, Lemon Committee dilantik oleh Pesuruhjaya Tinggi Negeri-negeri Melayu Bersekutu untuk mengkaji dan melaporkan cara terbaik bagi memberikan pelajaran teknik dan perusahaan. Anggota jawatankuasa ini terdiri daripada A.H. Lemon sebagai pengerusi, W. George Maxwell, H.W. Firmstone dan juga J.H.M. Robson. Syor-syor jawatankuasa tersebut adalah seperti berikut:

i. Menyediakan sekolah pertukangan yang terbuka bagi kanak-kanak semua kaum yang boleh mengikuti pelajaran dalam bahasa Melayu.

ii. Penubuhan sekolah teknik di Kuala Lumpur untuk memberikan latihan dalam bahasa Inggeris dalam mata pelajaran seperti kejuruteraan mekanik dan elektrik dan kejuruteraan awam permulaan. 
iii. Pembukaan sebuah sekolah pertanian berhampiran dengan Kuala Lumpur selain daripada sebuah sekolah dalam bahasa sendiri dan sebuah kelas dalam bahasa Inggeris bagi pegawai-pegawai Jabatan Perhutanan.

iv. Perlunya memperbaiki tangga gaji dalam jawatan teknik supaya boleh menjadi sama menariknya seperti kerja kerani. ${ }^{54}$

v. Diadakan sebuah sekolah pertanian di sekitar Kuala Lumpur untuk melatih penolong Juruteknik Pertanian di Jabatan Pertanian dan di estet ${ }^{55}$ dan sekolah perdagangan untuk kanak-kanak semua bangsa yang boleh bertutur dalam bahasa Melayu. ${ }^{56}$

Berdasarkan syor jawatankuasa ini, lapan tahun kemudian sekolah pertukangan pertama didirikan di Kuala Lumpur. Sekolah pertukangan ini berjaya kerana dalam tempoh sembilan tahun berikutnya tiga lagi sekolah telah dibuka di Ipoh, Pulau Pinang dan Johor Baharu. ${ }^{57}$ Lima tahun kemudian Sekolah Pertanian dibuka di Serdang pada tahun 1931 yang menyediakan dua kursus pengajaran.Pertama ialah kursus setahun dalam Bahasa Melayu untuk latihan pegawai di jabatan-jabatan kerajaan dan kedua, kursus dua tahun dalam bahasa Inggeris. Apabila pelajar tamat pengajian, penuntut yang berjaya boleh memohon kerja sebagai pegawai rendah di Jabatan Pertanian atau sebagai tenaga pengajar tanaman getah di Pusat Penyelidikan Getah atau sebagai pembantu makmal.

Suruhanjaya Lemon yang dibentuk pada 1918 telah mencadangkan supaya kerajaan British melantik seorang berbangsa Eropah sebagai pengetua dan juga seorang Eropah dan India sebagai penolong pengetua. Sekiranya dua orang berbangsa Eropah tidak diperoleh, maka ia boleh digantikan oleh dua orang atau lebih orang India yang berkelayakan untuk membantu pengetua tersebut. Dalam urusan pembelian peralatan untuk kegunaan di makmalmakmal, sebuah jawatankuasa kecil telah ditubuhkan dengan diketuai oleh 3 orang dari Jabatan Kerja Raya, Jabatan Ukur serta Jabatan Keretapi.

Cadangan lain ialah kursus-kursus seperti Civil Engineering, Mathematics, Architecture, Electricity dan Magnetism, Prime Movers and Theory of Machines, Survey Computation, Railway Signalling and Telephone dan Telegraph Engineering diperkenalkan di sekolah teknik. Walau bagaimanapun, pihak sekolah telah mengambil keputusan bahawa hanya kursus-kursus yang diperlukan oleh jabatan-jabatan teknik sahaja yang akandisediakan.

Jabatan Pelajaran Persekutuan ada membuat laporan mengenai sekolah teknik ini. Dalam laporannya pada tahun 1935, jabatan itu telah menekankan bahawa selain daripada kelayakan yang ada pada diri seseorang itu, pelajar haruslah memiliki tubuh badan yang sihat dan mempunyai minat yang mendalam terhadap pelajaran tersebut.Untuk menambahkan ilmu pengetahuan serta pengalaman semasa belajar, kelas-kelas khas telah diadakan bagi para penuntut tahun tiga di Jabatan Ukur.Selain itu, penekanan juga telah diberikan kepada kelaskelas Ilmu Hisab. ${ }^{58}$ Dengan kerjasama Jabatan kesihatan, kelas-kelas pertolongan cemas telah dibuka semula. Kelas ini penting kerana para pelajar harus tahu mengenai perkara-perkara berkaitan aspek berkenaan. Ini disebabkan muncul kekhuatiranakan berlaku kejadiankejadian yang tidak diingini semasa mereka menjalankan tugas mereka kelak.

\section{Suruhanjaya Mc Lean, 1939}

Pada tahun 1939, Suruhanjaya Mc Lean telah dibentuk untuk menyiasat kepentingan sekolah teknik di Tanah Melayu. Suruhanjaya dianggotai oleh W.H.Mc Lean (Pengerusi), H.J. Channon dan juga $\mathrm{H}$. North-Hunt yang telah memberikan laporan mengenai sekolah teknik. Suruhanjaya ini dilantik oleh setiausaha Negara-negara Koloni bagi pelajaran tinggi di Malaya (Secretary of The State For The Colonies On Higher Education In Malaya). Suruhanjaya ini telah memberikan beberapa alasan agar sekolah teknik ini terus diperbesarkan lagi. Antara syor-syor yang telah diberikan adalah seperti berikut: 
i. Bahawa Kuala Lumpur terletak di tengah-tengah negara dan banyak ibu pejabat di pelbagai jabatan terletak disana. Oleh yang demikian sekolah teknik akan dapat memberikan sumbangan yang lebih berkesan.

ii Tanah Melayu merupakan sebuah negara kecil. Oleh yang demikian adalah lebih praktikal untuk mendirikan sebuah institusi pengajian tinggi yang lengkap dan maju daripada membina beberapa buah sekolah tetapi kurang kemudahan di tempat-tempat lain.

iii. Suruhanjaya ini percaya bahawa sekolah teknik dengan perlahan-lahan akan muncul sebagai sebuah Maktab Teknik dengan memperluaskan dan memperbanyakkan lagi kursus-kursusnya serta mengharapkan taraf pelajarnya akan meningkat. $^{59}$

Syor-syor ini menunjukkan kerajaan dan jawatankuasa penasihat sekolah perlu berusaha untuk menjadikan sekolah teknik sebagai sebuah sekolah yang unggul di Tanah Melayu dalam bidang teknikal.

Pada tahun 1941, terdapat seramai 220 orang pelajar menuntut di sekolah teknik. Dari jumlah ini 90 orang terdiri daripada pelajar persendirian. ${ }^{60}$ Ini merupakan satu kemajuan yang pesat bagi pendidikan teknik.Masyarakat luar mula tertarik dan percaya terhadap bidang tersebut. Ini bermakna satu kejayaan besar bagi sekolah teknik kerana berjaya menarik minat masyarakat luar yang belum terlibat dalam bidang teknik. Contoh lain yang menunjukkan bahawa bidang teknik telah mendapat perhatian meluas ialah dimana seramai tiga ratus permohonan telah diterima oleh sekolah teknik, sedangkan hanya terdapat 40 kekosongan pada tahun $1941 .^{61}$

Selain itu, pada tahun 1942, sekolah teknik diubah nama dan seterusnya dinaikkan taraf menjadi Maktab Teknik Kuala Lumpur. ${ }^{62}$ Tujuan utamanya ialah untuk menaikkan statusnya disamping untuk mengelakkan kekeliruan masyarakat terhadap fungsi dan tujuan sekolah teknik dan juga 'Junior Technical (trade) School’ yang telah ditubuhkan. ${ }^{63}$

Semasa pendudukan Jepun dapat dikesan kerosakan pada bangunan Sekolah Teknik. Peralatan di makmal dan juga peralatan teknik yang lain banyak yang rosak dan hilang. Disamping itu banyak buku-buku rujukan di perpustakaan yang hilang. Walau bagaimanapun, beberapa peralatan yang penting di makmal percubaan telah terselamat. ${ }^{64}$

\section{Institusi Sains Penyelidikan}

Perkembangan ekonomi yang pesat di Negeri-negeri Melayu Bersekutu telah mendorong British mewujudkan institusi penyelidikan ekonomi untuk mencari punca masalah dan cara penyelesaian terhadap masalah tersebut. Hal ini penting kerana salah satu punca tanaman kopi tidak berjaya adalah disebabkan oleh ketiadaan institut yang membuat penyelidikan terhadap tanaman tersebut. Begitu juga dengan institut penyelidikan sosial penting dalam mencari penyelesaian terhadap masalah penyakit dalam kalangan penduduk terutama yang menyerang buruh Cina dan India.

Untuk memastikan keuntungan ekonomi yang diperoleh mencapai tahap maksimum, British telah menubuhkan beberapa institut yang dianggap boleh membantu mencapai matlamat mereka. Antara institut tersebut ialah, Institut Penyelidikan Hutan, Institut Penyelidikan Getah dan Institut Penyelidikan Perubatan.Ketiga-tiga institusi ini adalah institusi sains yang telah memainkan peranan dalam pembangunan ekonomi British di Tanah Melayu. 


\section{i. Institut Penyelidikan Hutan/Forest Research Institute (FRI)}

Organisasi penyelidikan perhutanan yang pertama telah ditubuhkan pada tahun 1918 di bawah Jabatan Perhutanan dan pegawai penyelidik pertama ialah Dr. F.W. Foxworthy seorang warga negara British. ${ }^{65}$ Kemudiannya ditubuhkan Institut Penyelidikan Perhutanan (FRI) secara rasmi pada 1929 yang kemudian muncul menjadi sebuah institusi yang terkemuka dalam penyelidikan perhutanan tropika di dunia. ${ }^{66}$ Pada tahun yang sama, organisasi tersebut telah dipindahkan ke Kepong yang dikenali sebagai Institut Penyelidikan Hutan. ${ }^{67}$ Institut initelah ditubuhkan di sebuah kawasan tapak lombong bijih timah di Kepong yang diusahakan sebagai kebun sayur dan secara rasmi mula beroperasi pada tahun 1929 . Terdapat satu faktor penting yang memudahkan kelulusan pembinaan Institut Penyelidikan Hutan iaitu wujudnya kesedaran bahawa hutan di Tanah Melayu mempunyai potensi yang sangat besar sebagai pembekal kayu-kayan, rotan, getah perca dan hasil sampingan lain. Selain itu hutan juga mempunyai peranan sebagai sumber bekalan air. Hal ini dinyatakan oleh Pesuruhjaya Tinggi dalam Majlis Mesyuarat Kerajaan pada tahun 1922. Menurut beliau:

... the only great natural resources which the country possesses, tin is wasting asset, the forest properly managed are asset of continually increasing value, and the government attached greatest important to their proper maintainenece not only as a source of revenue but on account of the many other benefit which accure from the possession of them. ${ }^{68}$

Pada tahun 1930, Dr.F.W. Foxworthy, pegawai penyelidik pertama dalam bidang perhutanan telah memulakan usaha penyelidikan perhutanan. Aktiviti penyelidikan perhutanan ketika itu merangkumi botani, silvikultur, ekonomi, kimia dan zoologi. Tapak semaian FRI yang ditubuhkan pada 1929 merupakan tapak semaian biji benih pokok hutan sebelum benih-benih atau anak pokok hutan ini dibekalkan untuk aktiviti penanaman. J.G. Watson yang berkhidmat di bawah Dr. F.W. Foxworthy sebagai Timbalan Pemelihara dan ahli ekonomi hutan telah memulakan usaha pembangunan arboreta atau koleksi tumbuhan hidup di FRI. Dalam tempoh antara tahun 1918-1941 sudah banyak penyelidikan hutan dijalankan oleh pihak Jabatan Hutan dan FRI (selepas ditubuhkan). Para saintis di Institut Penyelidikan Perhutanan di Kepong, Selangor telah berusaha mempercepatkan program penyelidikan mereka untuk mencari kayu yang terbaik. ${ }^{69}$ Antara penyelidikan yang telah dibuat adalah seperti Penyelidikan Perhutanan tertumpu pada Pengkajian Ciri-ciri Kayu, Penyelidikan Hasil Sampingan Hutan, Penyelidikan Serangga Perosak, Penyelidikan Kuantiti dan Penyebaran Kayu Dagangan di Tanah Melayu, Penyelidikan Masalah Silvikultur dan Cara Mengurus Hutan, Kajian Sifat Kimia Kayu, Kajian Serangga dan Kulat, Kajian Sifat Mekanikal dan Fizikal Kayu Tempatan, Kajian Silvikultur dan Kajian Pemulihan Hutan

Pencapaian FRI dalam penyelidikan kayu telah menarik perhatian pakar-pakar penyelidik dan golongan intelektual dari luar negara. Contohnya pada 17 Mac 1937, 20 pegawai perhutanan Tanah Melayu dan perwakilan dari luar seperti Mr. A.J. Beversluis, Inspektor Perhutanan Netherlands India, Mr. B.J.C. Spurway, Pegawai Kanan Perhutanan Sarawak dan Mr. H.G. Keith, konservator hutan Borneo Utara telah menghadiri persidangan perhutanan kali ketiga di Kepong. ${ }^{70}$ Dalam tempoh 10 tahun selepas FRI memulakan aktiviti penyelidikan, ia menjadi tumpuan ahli sains dan penyelidik perhutanan mendalamkan pengetahuan mereka tentang kayu-kayan di Timur Jauh. Hal ini dikuatkan oleh pernyataan Prof. C.A Middleton Smith: 
...strongly recommends every engineer interested in timber to visit the Research Institute... The Forest Research Institute at Kepong might be accepted as a pattern by other government, such as Siam and other timber-producing countries in the Far East. $^{71}$

Dalam usaha menyelidik dan meningkatkan hasil hutan di Tanah Melayu, FRI telah mencapai beberapa kejayaan. Kejayaan tersebut dapat dibuktikan melalui pencapaian berikut:

\section{a. Peningkatan Hasil Pendapatan}

Dalam tahun 1915, hutan hanya menghasilkan pendapatan berjumlah \$514, 784.00. Namun eksport kayu dari Tanah Malayu pada tahun 1935 telah melebihi beberapa ribu tan berbanding eksport tahun $1934 .^{72}$ Dalam tahun 1929 pula hasil eksport kayu telah meningkat menjadi \$2,302,395.00. Ini bererti jika dibuat perbandingan eksport kayu tahun 1915 dengan eksport kayu 1929 berlaku peningkatan pendapatan sebanyak 347.8\%.

\section{b. Penemuan Jenis Kayu Bermutu Tinggi}

Kejayaan penyelidikan FRI dapat dibuktikan dengan penggunaan jenis kayu resak yang dahulunya tidak popular tetapi kini telah menggantikan kayu cengal dan merbau dalam pembinaan landasan kereta api.

\section{c. Penerbitan Buku}

Berasaskan usaha penyelidikan, FRI telah mengeluarkan beberapa siri penerbitan. Antaranya ialah Commercial Woods of The Malay Peninsular (1921), Minor Forest Product of the Malay Peninsular (1922), Commercial Timber Trees of the Malay Peninsular (Illustrated 1927), Notes On Damar Penak (1929), Malayan Plant Names (1928) dan The Mangroove Forest of the Malay Peninsular (1929). ${ }^{73}$

Selain itu pada tahun 1936, hasil penyelidikan terperinci dan teliti yang dilakukan oleh FRI telah terbukti membantu industri perkayuan. Tanah Melayu telah mendapat manfaat sejumlah £10,000 kerana keputusan Pentadbir Angkatan Tentera Laut British untuk menggunakan kayu dari Tanah Melayu untuk membina blok baru di Pangkalan Tentera Laut, Seletar. Keputusan ini dibuat selepas pihak pemerintah angkatan tentera yakin dengan hasil penelitian yang telah dilakukan oleh FRI. ${ }^{74}$

Menerusi penyelidikan dan penerokaan yang dibuat oleh FRI, ia telah berjaya mengenengahkan kepada pengetahuan dunia bahawa kayu-kayan Tanah Melayu adalah pelbagai jenis dan sangat bernilai. Keputusan untuk menjadikan Tanah Melayu sebagai pembekal kayu kepada seluruh empayar British adalah berkait dengan dasar kerajaan British yang berkehendakkan Negeri-negeri Melayu (NNM) menghasilkan kayu-kayan yang mencukupi bagi kegunaan tempatan dan luar negeri.

Institut ini telah menjamin pemeliharaan hutan dan penghasilan hutan yang berkualiti untuk membantu sektor pertanian dan perlombongan.Kewujudan institusi ini juga telah menjamin penerokaan hutan yang terkawal dan penghasilan hutan yang mencukupi untuk membangunkan ekonomi NNM.

\section{ii. Institut Penyelidikan Getah/Rubber Research Institute (RRI)}

Di Malaysia usaha penyelidikan getah bermula pada tahun 1903 dan kerajaan berpendapat supaya penyelidikan dipesatkan lagi sehingga penubuhan Institusi Penyelidikan Getah (RRI) pada 26 Jun $1925 .{ }^{75}$ Sebelum penubuhan, beberapa pusat penyelidikan dan organisasi berjuang bagi kepentingan industri getah telah muncul di Tanah Melayu. Di antaranya adalah Rubber Grower's Association (RGA), JabatanPertanian NNMB (1905), Persatuan Pertanian 
Negeri Melayu di Semenanjung Tanah Melayu dan Society Financiere des Caoutchouces. Semua organisasi ini telah berhenti menjalankan operasi masing-masing sebaik sahaja RRI ditubuhkan. Apabila RRI ditubuhkan, para pegawai dan kakitangan RGA yang terlibat dalam penyelidikan saintifik telah dipindahkan ke RRI. Dalam akhbar The Straits Times tahun 1935 telah melaporkan bahawa penanam getah ketika itu telah menjadi sesuatu yang saintifik dan para penanam getah perlu mempunyai pengetahuan yang praktikal tentang tanah. ${ }^{76}$

Menjelang Perang Dunia I (1914-1917) usaha-usaha penyelidikan getah yang dilakukan oleh Jabatan Pertanian adalah membanggakan tetapi badan ini telah mengalami pelbagai masalah. Pengarah Pertanian Negeri-negeri Melayu Bersekutu, J.B. Carruthers mendapati kebanyakan kerja penyelidikan yang dilakukan pada masa itu tertumpu pada kegiatan menghapuskan tumbuh-tumbuhan liar yang tumbuh di ladang-ladang getah. Penghapusan tumbuh-tumbuhan liar ini merupakan aspek paling penting dalam proses menanam anak-anak pokok getah sebelum ia membesar. Masalah yang lain pula adalah terlalu banyak cahaya matahari dan ini disusuli dengan hujan yang turun dengan lebatnya menyebabkan pokokpokok getah kehilangan nutriennya dan mengubah lapisan atas tanah yang diusahakan tadi. Keadaan ini menjejaskan penanaman pokok-pokok getah. ${ }^{77}$

Pada tahun 1918, seorang pakar mithologi dari kerajaan India iaitu E.J. Butler telah diminta oleh Pesuruhjaya Tinggi Tanah Melayu iaitu Sir L.N. Guillemard untuk membuat laporan mengenai kedudukan kedua-dua badan penyelidikan ini. Pada bulan September 1918 beliau telah mengadakan perundingan di antara wakil-wakil RGA, Planters' Association of Malaya, agensi houses serta dengan kerajaan British. Dalam perundingan ini beberapa syor telah dikemukakan. Antaranya adalah sebuah badan penyelidikan getah akan dibentuk di Tanah Melayu dan badan ini mempunyai kuasa penuh untuk menjalankan segala penyelidikan berkaitan dengan industri getah. ${ }^{78}$ Mereka juga mengesyorkan pembentukan sebuah stesen penyelidikan getah yang akan dipusatkan di Kuala Lumpur. Kerajaan Negerinegeri Melayu Bersekutu harus memikul tanggungjawab terhadap hampir keseluruhan kos yang terlibat dalam pembentukan badan penyelidikan ini iaitu sebanyak $\$ 8,7500$ (tidak termasuk kos tanah) dan \$29,200 akan ditanggung melalui duti eksport getah. ${ }^{79}$ Sementara itu penyelidikan semasa Perang Dunia I masih diteruskan oleh Jabatan Pertanian tetapi pada tahap yang lebih perlahan. ${ }^{80}$

Institut Penyelidikan Getah telah banyak mengkaji mengenai getah dan penggunaannya.Banyak produk dan penemuan baru yang telah terhasil daripada penyelidikan di institut ini. ${ }^{81}$ Institut Penyelidikan Getah telah melakukan pelbagai kajian terbaik untuk membantu eksperimen syarikat perladangan dan estet-estet persendirian yang telah dijalankan di pelbagai tempat dalam negara. Penyelidikan ini akhirnya telah banyak mempengaruhi teknik penanaman getah. ${ }^{82}$ Dalam akhbar The Straits Times 7 Ogos 1931 melaporkan bagaimanasaintis dapat membantu para penanam getah dalam melawan serangan serangga dan penyakit. Dalam laporan ini dinyatakan bahawa saintis RRI boleh bertindak sebagai penasihat kerja, membantu dalam segi penambahbaikan teknik pembajaan, pemuliharaan tanah, teknik tanaman tutup bumi dan cara menghalang hakisan tanah, penghasilan tunas getah yang lebih bermutu, cara menghasilkan klon getah yang bermutu tinggi, cara menangani masalah penyakit getah seperti penyakit kulit dan batang getah, cara menangani masalah kerosakan getah disebabkan serangan haiwan, teknik pembasmian kuman tunas, penyelidikan terhadap susu getah, teknik memekatkan susu getah, teknik menghasilkan kepingan getah dengan penggunaan mesin khas dan teknik mengeringkan kepingan getah menggunakan teknik smoked houses. ${ }^{83}$

Institut penyelidikan getah merupakan badan penyelidik utama kerana ia berjaya meningkatkan pengeluaran getah asli di Tanah Melayu sehingga membolehkan negara menjadi pengeluar getah asli terkemuka dunia. Institut ini juga berperanan menyiasat segala masalah berkaitan dengan penghasilan susu getah. Selain itu RRI juga membekalkan 
maklumat berkaitan dengan getah kepada para penanam getah di Tanah Melayu. Para penanam getah dari negara Britain, Borneo Utara, Brunei, Nigeria dan Sarawak turut menerima khidmat nasihat ${ }^{84}$ dari RRI. RRI juga berperanan dalam menghasilkan benih-benih getah yang lebih baik untuk menjamin perolehan yang tinggi. Walaupun industri tanaman komersil seperti kopi telah mengalami kemerosotan, industri getah tetap dianggap mempunyai potensi yang tinggi untuk menghasilkan barangan baru seperti tayar, sarung tangan dan tiub getah. RRI juga berperanan menyelidik cara pembiakan dan memilih klonklon yang baik untuk menghasilkan baka bijih benih yang bermutu dan meningkatkan penghasilan susu getah yang bermutu tinggi. Antara kaedah pembiakan yang dilakukan oleh RRI adalah pendebungaan tangan, percantuman jemala, percantuman baji dan pembiakan tisu. RRI juga telah memberikan perhatian utama terhadap kaedah-kaedah penorehan pokok getah yang moden dan saintifik. Pengubahsuaian juga dilakukan terhadap kaedah torehan yang diperkenalkan oleh H.N. Ridley. ${ }^{85}$ RRI bertanggungjawab menyumbangkan sebahagian besar perbelanjaan untuk mengendalikan penggunaan kaedah-kaedah saintifik terhadap industri getah asli. Bukti kejayaan RRI meningkatkan hasil getah jelas dapat dilihat pada tahun 1937. Pada tahun tersebut Tanah Melayu telah berjaya mengeluarkan getah hampir 500,000 tan (dalam tahun 1900 negeri-negeri timur hanya berjaya mengeluarkan tidak sampai 500 tan). Pengeluaran getah ini tidak terjejas walaupun pada tahun 1930 harga getah di Tanah Melayu hanya 5 sen sekati (berbanding pada sekitar tahun 1909/1910 harga getah mencecah $\$ 3$ wang Amerika). ${ }^{86}$ Kejayaan pengeluaran getah yang melonjak ini sudah pasti berkait rapat dengan sumbangan penyelidikan yang dilakukan oleh Institut Penyelidikan Getah.

Dalam melaksanakan kerja-kerja saintifik, Institut Penyelidikan Getah dianggap sangat penting kerana penyelidikan yang dibuat untuk penambahbaikantanaman dan pengurusan tanah yang lebih baik amat diperlukan oleh industri untuk menyelesaikan masalah yang mereka hadapi berkaitan dengan penanaman getah. ${ }^{87}$ Terbukti bahawa RRI telah berjaya memainkan peranan penting dalammeningkatkan penghasilan para penanam getah di Tanah Melayu.

\section{iii. Institut Penyelidikan Perubatan}

Institut Penyelidikan Perubatan telah ditubuhkan di Kuala Lumpur pada tahun $1900{ }^{88}$ Kuasa pentadbiran dan tenaga perubatan bersatu untuk merealisasikan penubuhan Institut Penyelidikan Perubatan. Frank Swettenham dan Joseph Chamberlain merupakan dua kuasa pentadbir tertinggi yang berperanan penting ${ }^{89}$ sementara di pihak tenaga perubatan pula, Dr.Manson. ${ }^{90}$ Perlantikan Dr. Patrick Manson pada 7 Julai 1897 sebagai Penasihat Perubatan untuk Pejabat Tanah Jajahan yang baru membuktikan komitmen Chamberlain. ${ }^{91}$ Keprihatinan Joseph Chamberlain, Setiausaha Negara untuk Tanah Jajahan terhadap penyakit mulai meningkat dan beliau memberi perhatian khusus kepada kesan perkembangan parasitologi dan bakteriologi terhadap tanah jajahan. Sehingga abad ke-19, negeri-negeri di Tanah Melayu terutamanya di kawasan bandar disifatkan sebagai sesak dan kotor berikutan pertambahan penduduk berlaku begitu pesat. Pertumbuhan penduduk di Pulau Pinang dan Province Wellesly umpamanya, meningkat daripada 133,230 orang kepada 247,808 orang antara tahun 1871sehingga tahun 1901. Melaka juga menyaksikan peningkatan jumlah penduduk daripada 77,756 orang kepada 95,487 orang pada tempoh yang sama. Manakala, di Perak peningkatan penduduk adalah daripada 214,254 orang pada tahun 1891 kepada 329,665 orang pada tahun 1901. Peningkatan yang besar juga dapat dilihat di Selangor iaitu daripada 81,592 orang pada tahun 1891 kepada 168,789 orang pada tahun $1901 .^{92}$ Keadaan tersebut mempercepatkan proses penularan wabak penyakit berjangkit. Permasalahan kesihatan yang melibatkan buruh asing seumpama ini dilaporkan pernah berlaku di Papua New Guinea. ${ }^{93}$ Menurut J. Norman Parmer: 


\begin{abstract}
British rule first made the incidence of disease and death very much worst than before. The clearing of land for estates, the expansion of mining and the construction of public works disturbed existing ecological balances, causing disease to spread and multiply. The large immigrant labour forces assembled for these capital investments lacked natural immune systems. The colonial government, the chief provider of medical services, also lacked experience and knowledge and as a consequence many tens of thousands of workers died. ${ }^{94}$
\end{abstract}

NNMB dipilih memandangkan berlakunya penularan serius dua penyakit tropika pada ketika itu iaitu beri-beri dan malaria. Penularan penyakit dilihat sebagai penghalang kepada

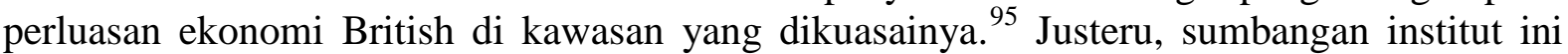
terhadap pengetahuan berkenaan beri-beri dan penyakit tropika yang lain amat besar maknanya. Bagi menampung bekalan doktor yang dilatih secara tempatan sebuah sekolah perubatan yang dinamakan Straits and Federated Malay States Government Medical School telah dibuka dengan rasminya di Singapura pada 18 September 1905. Pada tahun 1913 nama sekolah ini telah diubah namanya menjadi "King Edward VII Medical School” yang terletak di Singapura. ${ }^{96}$ Kumpulan pertama sekolah ini telah menerima diploma Licentiate in Medicine and Surgery pada bulan Mei 1910. Penularan penyakit beri-beri, malaria dan penyakit disenteri di NNMB antara 1896 hingga 1941 berkait langsung dengan perkembangan kegiatan ekonomi komersial British. Penerokaan kawasan baru untuk pertanian, perlombongan, kemudahan infrastruktur dan petempatan telah mengganggu ekosistem yang wujud di kawasan tersebut. Hal ini menyebabkan berlakunya serangan penyakit. Penubuhan institusi ini telah berjaya mencari punca untuk mengatasi dan mencari ubat atau penawar bagi mengubati penyakit-penyakit tropika seperti beri-beri dan malaria yang telah banyak mengorbankan nyawa pada masa tersebut terutama terhadap imigran India dan China. Misalnya pada tahun 1913, satu resolusi muktamad tentang punca beri-beri dan penyelesaiannya telah dicapai.Ia dibacakan dalam kongres ketiga Far Eastan Association of Tropical Medicine yang diadakan di Saigon dari 8 hingga 15 November 1913. Resolusi tersebut berbunyi:

That in the opinion of this Association it has been proved that beri-beri is caused by a deficiency in diet of certain substances of which the exact nature is still unkown. That such substances are present in sufficient amount in unpolished rice. That therefore it is advised that the Governments of those countries where rice forms the staple article of diet should encourage by all possible means the use of unpolished rice. ${ }^{97}$

Sebagai tenaga yang mengkhusus dalam kajian saintifik tentang malaria, kakitangan Institut Penyelidikan Perubatan turut mengetengahkan pandangan mereka terhadap langkahlangkah pengawalan malaria yang dijalankan oleh tenaga perubatan negeri. Dalam hal ini, Dr. Henry Fraser, pengarah ketiga institut mengemukakan pandangan beliau berkenaan beberapa perkara, antaranya ialah kepentingan penggunaan kuinina secara sistematik dan kuaters kalisnyamuk untuk buruh estet; kesesuaian kaedah penyaliran untuk kawasan bandar berbanding dengan kawasan pedalaman; keperluan untuk menyelidik dengan lebih mendalam keberkesanan penggunaan sejenis ikan dari Berbados iaitu millions sebagai agen penghapus larva nyamuk ${ }^{98}$ dan ketidaksesuaian kaedah penyemburan minyak kerosin di atas permukaan kolam yang kecil. ${ }^{99}$ Pandangan paling bernas yang beliau utarakan adalah berkenaan kaedah 
sistem penyaliran dan penggunaan kuinina yang menimbulkan kontroversi dalam kalangan tenaga perubatan. Dr. Fraser menyatakan:

A controversy has recently arisen on drainage versus quinine prophylaxis, it would be futile to enter into such a controversy for a method which gave execellent results in one place might prove quite impracticable in another. ${ }^{100}$

Penyelidikan serius yang dilakukan oleh kakitangan Institut Penyelidikan Perubatan terhadap jenis disenteri adalah lewat berbanding dengan beri-beri dan malaria. Walaupun Dr. R.S. Milne terlibat dalam kajian bakteriologi disenteri yang pelbagai seawal tahun $1903^{101}$ tetapi penyelidikan terhadap disenteri ameba hanya dijalankan pada tahun $1913^{102}$ manakala ciri-ciri disenteri basilus pada tahun berikutnya. ${ }^{103}$ Bukti kejayaan institut ini dapat dilihat seperti berikut:

1. Penyakit Beri-Beri

1900 Kes dirawat 11,072 org

Kes kematian $\quad 1,450$

\% kematian $\quad 13.1 \%$

1914 Kes dirawat 6,240 org

Kes kematian 686

\% kematian $\quad 11.0 \%$

Sumber: Disesuaikan daripada FMSAR 1908, hlm. 28; FMSAR 1909, hlm. 27; FMSAR 1912, hlm.32 dan FMSAR 1913, hlm. 29.

\section{Penyakit Disenteri}

1900 Kes dirawat

Kes kematian 1,356

\% kematian 28.2\%

1914 Kes dirawat 5,982

Kes kematian $\quad 1,429$

\% kematian $\quad 23.9 \%$

Sumber: Disesuaikan daripada Laporan Tahunan dan Laporan Perubatan Perak, Selangor, Negeri Sembilan dan Pahang, 1900 dan 1914: PKAR 1900, h. 50; PKAR 1914, h. xv; SAR 1901, h. xxv; SAR 1914, h. xvii; NSAR 1900, h. xvi; NSAR 1914, h. 18; PHGAR 1900, h. xii; dan PHGAR 1914, h. 26.

3. Penyakit Malaria

1900 Kes dirawat 11,554 org

Kes kematian $\quad 484$

$\%$ kematian $\quad 4.2 \%$

1914 Kes dirawat 29,727

Kes kematian 1,793

\% kematian $\quad 6.0 \%$ 
Sumber: Disesuaikan daripada FMSAR 1908, hlm. 27; FMSAR 1909, hlm. 27; FMSAR 1910, hlm. 2, dalam SFMSGG 1911; FMSMR 1911, hlm. 3, dalam SFMSGG 1912 dan FMSMR 1914, hlm. 2, dalam SFMSGG 1915.

Pengiktirafan terhadap peranan yang dimainkan oleh IMR dapat dilihat melalui Laporan Jawatankuasa Penyelidikan Perubatan pada tahun 1928 yang mendapati institusi ini perlu mendapat peningkatan peruntukan sejajar dengan reputasi antarabangsanya. ${ }^{104}$ Sekitar tahun 1930 pula Institut Penyelidikan Perubatan, Kuala Lumpur berjaya menerbitkan dua buah buku iaitu "Observation on Some Factors Influencing the Infectivity of Malarial Gamete Carriers in Malaya to Anopheles Maculatus" yang ditulis oleh Dr. Richard Green dan "The Rubine Reaction in Leprosy” tulisan Dr. C. Russel Amies. ${ }^{105}$ Buku ini telah banyak membantu masyarakat dan para pengkaji memahami penyakit malaria dan kusta.Dalam laporan akhbar The Singapore Free Press and Mercantile Advertiser, 7 Oktober 1940 menyatakan bahawa keputusan pelaksanaan tugas anti malaria di Tanah Melayu adalah sangat mengagumkan, kebanyak bandar hampir bebas malaria dan kebanyakan ladang-ladang getah dikatakn telah bebas dari masalah penyakit malaria. ${ }^{106}$ Kejayaan penyelidikan yang telah dijalankan oleh institut ini telah menjamin kewujudan tenaga buruh yang sihat dan dapat memenuhi keperluan industri getah dan perlombongan bijih timah British di Tanah Melayu.

\section{Kesimpulan}

Penubuhan institusi sains dan penyelidikan di Negeri-negeri Selat dan Negeri-negeri Melayu Bersekutu mempunyai kaitan yang sangat signifikan dengan perkembangan ekonomi. Pembangunan infrastruktur yang pesat menyebabkan British memerlukan pakar teknikal yang terlatih dalam pelbagai bidang profesional. Sebelum penubuhan institusi sains di Negerinegeri Melayu Bersekutu, hasil yang diperoleh oleh British di Tanah Melayu agak kurang menguntungkan dan industri berhadapan dengan pelbagai masalah. Hal ini disebabkan kekurangan tenaga kerja terlatih yang amat diperlukan di jabatan-jabatan kerajaan. Walau bagaimanapun apabila pendidikan sainsdiperkenalkan dalam kalangan masyarakat tempatan, maka ia secara tidak langsung telah dapat menyelesaikan masalah kekurangan tenaga kerja di jabatan-jabatan kerajaan seperti di Jabatan Kereta Api, Jabatan Kerja Raya, Juru Ukur dan Juru X-ray di hospital. Kewujudan institusi sains ini amat penting kerana ia berpengaruh besar keatas kelangsungan pemerintahan British di Tanah Melayu.

Penubuhan institusi sains di peringkat sekolah dan pengajian tinggi telah berjaya melahirkan tenaga kerja yang mempunyai pendedahan sains dan teknologi. British mengambil inisiatif menjadikan mata pelajaran sains dan teknik sebagai mata pelajaran wajib di peringkat sekolah menengah. Raffles College dan Institusi Victoria antara contoh institusi yang telah memainkan peranan penting dalam pelaksanaan menjayakan matlamat pihak British. Matlamat pentadbiran British melahirkan gunatenaga yang lebih mahir dapat dicapai dengan mewajibkan mata pelajaran sains di sekolah-sekolah Inggeris. Matlamat inilah yang menyebabkan British mula merancang sukatan pelajaran yang selaras bagi mata pelajaran sains dan teknik.

Aspek ini menjadi asas penting untuk mencapai matlamat yang lebih penting pada masa hadapan iaitu untuk tujuan penyelidikan bagi menangani masalah-masalah yang berkaitan dengan ekonomi British di Tanah Melayu. Sebagai contoh penubuhan Institut Penyelidikan Hutan selain untuk tujuan eksport, berkait rapat dengan penyelidikan mengenai penggunaan tanah secara optimum dan membuat penyelidikan mengenai kegunaan kayu-kayan yang ada di Tanah Melayu. Begitu juga dengan penubuhan Institut Penyelidikan Getah yang berperanan membuat penyelidikan untuk menyelesaikan masalah yang berkaitan dengan penanaman getah seperti masalah penyakit, cara penanaman getah dan cara meningkatkan pengeluaran getah. Ketiadaan institut seumpama ini adalah antara penyebab industri kopi 
tidak berjaya. Institut Penyelidikan Perubatan pula ditubuhkan untuk mencari punca penyakit yang mengancam kesihatan penduduk tempatan dan buruh asing dari Cina dan India. Dalam hal ini ancaman penyakit jika tidak dapat diselesaikan boleh menjejaskan ekonomi Tanah Melayu kerana ketika itu kebergantungan British terhadap buruh asing sangat tinggi. Amat jelas penubuhan institusi sains dalam bidang pendidikan dan penyelidikan telah membantu dalam pengukuhan pemerintahan British di Tanah Melayu

\section{Nota}

${ }_{1}^{1}$ Awang Had Salleh, “Teknologi Dalam Pendidikan”, Dewan Masyarakat, Ogos 1985, hlm. 40.

${ }^{2}$ Philip A. Cogin, Technology And Man, Exeter: Wheaton and Co. Ltd., 1980, hlm. 22.

${ }^{3}$ Sybil P. Paker (ed), Concise Encyclopedia of Science And Tecknology, New York: Mcgraw-Hill Inc., 1984, hlm. 1534.

${ }^{4}$ James R. Newman, The Harper Encyclopedia of Science, New York: Haper and Row, 1967, hlm. 1847.

${ }^{5}$ http://prpm.dbp.gov.my/

${ }^{6}$ McGraw-Hill, Encyclopedia Of Science And Tecknology, New York: McGraw-Hill Inc., 1982, Vol. 12, hlm. 110.

${ }^{7}$ David Dickson, The Politics of Alternative Technology, Second Printing, New York: Universe Books, 1975.

${ }^{8}$ William F. Cottrell, Technology, Man and Progress, Ohio: Charles E.Merill Publishing C., 1971, hlm. 11.

${ }^{9}$ Kasim Kasimin, "Sejarah Pelajaran Teknik di Malaysia: Semenjak Penubuhan dan Perkembangan Sekolah Teknik, Maktab Teknik dan Universiti Teknologi Malaysia (1906-1982)”, Latihan Ilmiah, Universiti Teknologi Malaysia, 1989, hlm. 4.

${ }^{10}$ T.C. Collocott And A.B. Dobson, Chambers Dictionary Of Science And Techonology, Sufflok: Richard Clay, 1982, hlm. 1036.

${ }^{11}$ Donald Mckenzie and Judy Wajeman, The Social Shaping of Technology, Milton Keynes: Open University Press, 1985, hlm. 9.

${ }^{12}$ Robiah Sidin, Pendidikan Di Malaysia: Cabaran Untuk Masa Depan, Kuala Lumpur: Penerbit Fajar Bakti Sdn. Bhd., 1994, hlm. 87.

13 Zaidatol Akmaliah Lope Pihie, "Perkembangan Pendidikan Vokasional dan Teknik”, Kertas Kerja dalam Seminar Dalaman, Universiti Kebangsaan Malaysia, Bangi (tidak diterbitkan), 1986.

14 United Nations Educational, "Scientific and Cultural Organization," http://www.unesco.org/new/en/newdelhi/areas-of-action/education/technical-vocational-education-and trainingtvet/

${ }^{15}$ Philip Loh Fook Seng, Seeds Of Separatism, Educational Policy In Malaya 1874-1940, Kuala Lumpur: Oxford University Press, 1975, hlm. 1.

${ }^{16}$ D.D. Chelliah, A Short History of the Educational Policy of the Straits Settlements 1800-1925 [circa], Kuala Lumpur: Cetakan Kerajaan, 1947, hlm. 37.

${ }^{17}$ Ibid.

${ }^{18}$ Ibid., hlm. 14.

${ }^{19}$ Department of Education Annual Report, 1949, hlm. 2.

${ }^{20}$ http://www.eresource.nlb.gov.sg/Infopedia/articles/SIP-781-2005-01-03.html

${ }^{21}$ D.D. Chelliah, A Short History of the Educational Policy of the Straits Settlements 1800-1925, hlm. 12.

${ }^{22}$ Litografi adalah suatu cara pencetakan lukisan dengan memindahkan bayangan lukisan di atas cetakan. Litografi ditemukan pada 1788 oleh seorang tukang cetak Jerman bernama Aloy Senefelder. Litografi adalah hasil penelitiannya untuk mencari teknik cetak yang murah. Meskipun ditemukan di Jerman, secara keseluruhan, perkembangan terbesar litografi terjadi di Paris, tempat tinggal para pencetak litografi yang berdedikasi.

${ }^{23}$ Keasberry memulakan usaha menggalakkan minat membaca dengan mengeluarkan buku percuma, termasuk buku cerita untuk kanak-kanak. Dia merupakan salah seorang daripada segelintir mubaligh yang berupaya memenangi hati orang Melayu. Dia juga menubuhkan sekolah rendah percuma untuk masyarakat Melayu di Singapura.Sekolah percuma itu ialah institusi pertama di Singapura yang menggabungkan kerja manual dengan kurikulum sekolah. Tujuannya adalah supaya semua pelajarnya biasa dengan hal ehwal perniagaan yang berkaitan dengan industri percetakan. Sebagai contoh, percetakan, penjilidan buku dan litografi selain yang boleh membaca dan menulis. Tokoh ini berkait rapat dengan penubuhan “Mission Press” di Singapura.

${ }^{24}$ Ibid., hlm. 111. 
${ }^{25}$ Francis Wong Hoy Kee dan Ee Tiang Hong, Pendidikan di Malaysia, Kuala Lumpur: Heineman Education Books (Asia) Ltd., 1974, hlm. 41.

26 Ibid.

${ }^{27}$ Merujuk kepada undang-undang bertajuk "An Ordinance to provide for the Establishment of a School of Medicine at Singapore” yang diluluskan oleh Majlis Perundangan Negeri-negeri Selat pada 14 Julai 1905.

${ }^{28}$ Noraini Mohamed Hassan dalam jurnal sejarah "Tercapainya Sebuah Impian, Berakhirnya Satu Penantian:

Ordinan No.XV, 1905, Negeri-negeri Selat dan Perkembangan Maktab Perubatan Raja Edward VII, Singapura, 1905-1941”, menjelaskan bahawa penulis artikel ordinan no. XV, 1905 telah menggunakan perkataan maktab bagi merujuk Maktab Perubatan Raja Edward VII meskipun di peringkat awal penubuhannya iaitu dari tahun 1905 sehingga 1921, perkataan sekolah telah terlebih dahulu digunapakai dalam keadaan yang bersesuaian dan membawa makna yang sama.

${ }^{29}$ Latar Belakang Universiti Malaya http://www.um.gov.my, 25 Mac 2003.

${ }^{30}$ Lee Chee Ying, "Sejarah Perkembangan Latihan Perguruan di Malaysia: Satu Tinjauan," Pulau Pinang, Jld.3, Bil. 1, Jan. 1981.

31 “Seabad Meniti Cabaran Menjana Peradaban Terbilang: 100 Tahun Sejarah UTM (1904-2004)”, hlm. 3.

${ }^{32}$ Ibid.

${ }^{33}$ Philip Loh Fook Seng, Seeds Of Separatism, Educational Policy In Malaya 1874-1940, hlm. 111.

34 “Seabad Meniti Cabaran Menjana Peradaban Terbilang: 100 Tahun Sejarah UTM (1904-2004),” Universiti Teknologi Malaysia, 2005, hlm. 3.

${ }^{35}$ Ibid., hlm. 9.

36 “Report of the Science in Schools Committee,” The Federated Malay States Government Press, 1940, hlm. 1.

37 "Report of The Science in School Committee", The Federated Malay States Government Press, 1941, hlm. 1.

${ }^{38}$ Ibid.

39 “Seabad Meniti Cabaran Menjana Peradaban Terbilang: 100 Tahun Sejarah UTM (1904-2004),” hlm. 9.

${ }^{40}$ Ibid.

41 Tahun tidak dapat dikesan.

${ }^{42}$ General Science Sub-Committee, Report on The Teaching of General Science, London: Butler and Tanner Ltd., 1950, hlm. 9.

${ }^{43}$ Ibid.

${ }^{44}$ H.R. Cheesman, “Annual Report”, 1947, hlm. 9.

45 John G. Butcher, The British In Malaya 1881-1941, Kuala Lumpur: Oxford Press, 1979, hlm. 36.

46 Regulation for Malay Vernacular Education, "The General Science Course in The Federated Malay State,"1936, hlm. 78.

${ }^{47}$ Ibid., hlm. 10.

48 "Report on Teaching of General Science", hlm. 2-3.

${ }^{49}$ Ibid., hlm. 13.

${ }^{50}$ Report of the Science in Schools Committee, The Federated Malay States Government Press, 1941, hlm. 1.

${ }^{51}$ Ibid., hlm. 1-2.

52 “Seabad Meniti Cabaran Menjana Peradaban Terbilang: 100 Tahun Sejarah UTM (1904-2004),” hlm. 5.

${ }^{53}$ Ibid.

${ }^{54}$ Ibid., hlm. 112.

${ }^{55}$ F.J. Morten, Annual Report of Education Department For The Year 1934, Kuala Lumpur: Government Press, 1935, hlm. 8.

56 "Laporan Jawatankuasa Lemon mengenai Pelajaran Teknik dan Perusahaan di Negeri-negeri Melayu Bersekutu,” 1918.

${ }^{57}$ Ibid.

${ }^{58}$ Selangor Secretariat, Annual Report Of Technical School 1935, Fail 56/1936

${ }^{59}$ Ibid., hlm. 158.

${ }^{60}$ H.R. Cheesman, Annual Report On Education In The Malayan Union For The Period $1^{\text {st }}$ April $1946-31^{\text {st }}$ Disember 1946, Kuala Lumpur: Government Press 1947, hlm. 56.

${ }^{61}$ H.R. Cheesman, "Education In Malaya”, dalam Colonial Office, Education In Malaya: 1930-1942, Kuala Lumpur: Government Press, 1948, hlm. 15.

${ }^{62}$ Francis Wong Hoy Kee dan Ee Tiang Hong, Education in Malaysia, Kuala Lumpur: Heineman Educational Book, 1974, hlm. 160.

${ }^{63}$ H.R. Cheesman, Annual Report On Education In The Malayan Union For 1947, Kuala Lumpur: Government Press, 1948, hlm. 19.

${ }^{64}$ H.R. Cheesman, Annual Report On Education In The Malayan Union For The Period $1^{\text {st }}$ April 1946-31 ${ }^{\text {st }}$ Disember 1946, Kuala Lumpur: Government Press, 1947, hlm. 4.

${ }^{65}$ Louis Ratnam, Windows on the Forest: Glimses of FRIM, Kepong: FRIM Publication, 1995, hlm. 13. 
${ }^{66} \mathrm{http}: / / \mathrm{http} / /$ www.frim.gov.my/about-us/overview/?lang=ms

${ }^{67}$ Ibid.

${ }^{68}$ Federated Malay State, Report of Forest Administration For The Year 1922, Kuala Lumpur: Government Press, 1923, hlm. 18.

${ }^{69}$ http://eresources.nlb.gov.sg/newspapers/Digitised/Article/straitstimes19551013-

1.2.75.aspx?q=Malayan+will+produce+its+own+paper\&page=1\&sort=relevance\&token=paper\%2cown\%2cits

\%2cproduce\%2cwill\%2cmalayan\&sessionid=0adb84babcf2428ea1f5de1c890706ed

${ }^{70} \mathrm{http}$ ://eresources.nlb.gov.sg/newspapers/Digitised/Article/singfreepressb19370319-

1.2.40.aspx?q=Forest+research+institute+in+british+malaya\&page=1\&sort=relevance\&token=malaya\%2cbritis h\%2cin\%2cinstitute\%2cresearch\%2cforest\&sessionid=9716a20ea66b48daa3386775ae8634a1

${ }^{71}$ J.P Mead, Annual Report On Forest Administration Federation Of Federation Malaya 1939, Kuala Lumpur: Government Press, 1940, hlm. 23.

${ }^{72}$ Ibid.

${ }^{73}$ G.E.S. Cubitt, Forest in Brtitish Malaya, A statement Prepared for the British Empire Forestry Conforence, Australia and New Zealand, Kuala Lumpur: FMS Government Printing, 1928, hlm. 18.

${ }^{74}$ http://eresources.nlb.gov.sg/newspapers/Digitised/Article/straitstimes19360510-

1.2.45.aspx?q=Forest+research+in+malaya\&page=2\&sort=relevance\&token=malaya\%2cin\%2cresearch\%2cfor est\&sessionid=520801e5c2064d0e964302fd71ee5f23

${ }^{75}$ Mohaine Khalid, "Penggunaan Rangkai Daun Getah Dalam Kreativiti Seni, Potensi Sebagai Bahan Gabungan Kepada: Fabrik, Pelekat, Kayu, Pelbagai daun Kering dan Logam”, Universiti Teknologi Mara, No. Fail Projek: 50014 (penyelidikan IRPA) 1998, hlm. 12.

${ }^{76}$ http://eresources.nlb.gov.sg/newspapers/Digitised/Article/straitstimes19350617-

1.2.50.aspx?q=is+forestry+ winning\&page=1\&sort=relevance\&token=winning\%2cforestry\%2cis\&sessionid=a7 00bcec96484180a600b2ef3d90e37e

77 J.H. Drabble, Rubber in Malaya 1876-1922: The Genesis of the Industry, Kuala Lumpur: Oxford University Press, 1973, hlm. 86.

78 E.J. Butler, "Memorandum on the Agricultural Department, Federated Malay States", Gazette of the Federated Malay States, $29^{\text {th }}$ April 1974.

${ }^{79}$ J.H. Drabble, Rubber in Malaya 1876-1922, hlm. 152.

${ }^{80}$ Ibid., hlm. 154.

81 Ibid.

${ }^{82}$ http://eresources.nlb.gov.sg/newspapers/Digitised/Article/straitstimes19350617-

1.2.50.aspx?q=is+forestry+ winning\&page=1\&sort=relevance\&token=winning\%2cforestry\%2cis\&sessionid=a7 00bcec96484180a600b2ef3d90e37e

${ }^{83}$ http://eresources.nlb.gov.sg/newspapers/Digitised/Article/straitstimes19310807-

1.2.108.aspx?q=how+the+scientist+helps+the+planter\&page=1\&sort=relevance\&token=planter\%2cthe $\% 2$ chelp s\%2cscientist\%2cthe\%2chow\&sessionid=f9bcc1b3c5624ca1a40ed2572018b6ef

${ }^{84}$ C.G. Akhurst, The Rubber Research Institute of Malaya: Agricultural Research Station’s Vol.5, hlm. 26.

${ }^{85}$ H.N. Ridley, gelarannya 'Bapa Perusahaan Getah Asli'.Beliau telah dilantik sebagai pengarah Taman Botanik di Singapura dan telah membuat penyelidikan yang pesat ke atas getah asli.

${ }^{86}$ http://eresources.nlb.gov.sg/newspapers/Digitised/Article/beritaharian19610202-

1.2.42.aspx?q=getah+1930\&page $=1$ \&sort=relevance\&token $=1930 \% 2$ cgetah\&sessionid=b58be0492dd04a4e934 $0681 \mathrm{e} 6 \mathrm{c} 66 \mathrm{~b} 5 \mathrm{c} 1$

${ }^{87}$ http://eresources.nlb.gov.sg/newspapers/Digitised/Article/straitstimes19280607-

1.2.69.aspx?q=Forest + research+institute+in+british+malaya\&page=2\&sort=relevance\&token=malaya\%2cbritis h\%2cin\%2cinstitute\%2cresearch\%2cforest\&sessionid=eac1f264902c49b28b8ec30a74de6e78

${ }^{88}$ http://www.imr.gov.my/my/corporate-info-2/sejarah.html

${ }^{89}$ Lihat High Commissioner’s Despacth File, Federated Malay States, 156/1899.

${ }^{90}$ Menurut Malay Mail, idea asal penubuhan institut ini dating dari Dr. Braddon dan Dr. H.A. Haviland. Perkara tersebut kemudiannya diajukan kepada Sir Michael Foster dan Dr. Manson yang bertindak sebagai jawatankuasa penimbang sebelum memutuskan pengambilan Dr. Hamilton Wright sebagai pengarah pertama (MM, 26 Julai 1902, hlm. 3).

${ }^{91}$ Lenore Manderson, Sickness and State: Health and Illness in Colonial Malaya 1870-1940, Cambridge: Cambridge University Press, 1996, hlm. 9.

92 Ibid., hlm. 38 dan 100.

93 Ibid., hlm. 30.

94 J. Norman Parmer, "Estate Workers' Health in the Federated Malay States in the 1920s", dalam Peter J. Rimmer \& Lisa M. Allen, The Underside of Malaysian History: Pullers, Prostitutions, Plantation Workers, Singapore: Singapore University Press, 1990, hlm. 179. 
${ }^{95}$ Noraini Binti Mohamed Hassan, "Penyakit Tropika di Negeri-negeri Melayu Bersekutu, 1896-1914: Tumpuan Kepada Penyakit Beri-beri, Malaria dan Penyakit Usus”, Disertasi Sarjana, Jabatan Sejarah, Fakulti Sastera dan Sains Sosial, Universiti Malaya, 2004, hlm. 4.

${ }^{96}$ Makepeace W, Brooke GE, Braddell RSJ, eds,.One Hundred Years of Singapore,Vol 1 \& 2, London: John Murray, 1921.

${ }^{97}$ Malay Mail, 29 November 1913, hlm. 7.

${ }^{98}$ Dr. Fraser melihat kebarangkalian yang tinggi untuk penggunaan ikan tersebut sebagai penghapus larva nyamuk sekiranya dibiakkan di kawasan takungan air yang besar seperti tasik. Masalahnya, larva nyamuk pembawa malaria membiak di kawasan yang lebih kecil dan berarus seperti kolam dan anak sungai.

${ }_{99}^{9}$ Institute Medical Research Annual Report for 1908, Kuala Lumpur: Government Press, 1909, hlm. 3.

${ }^{100}$ Ibid.

${ }^{101}$ Federated Malay State Annual Report for 1903,Kuala Lumpur: Printed at the F.M.S. Government Printing Office, 1904, hlm.35.

${ }^{102}$ Federated Malay State Annual Report for 1913,Kuala Lumpur: Printed at the F.M.S. Government Printing Office, 1914, hlm.39.

${ }^{103}$ Federated Malay State Annual Report for 1914, Kuala Lumpur: Printed at the F.M.S. Government Printing Office, 1915, hlm.24.

${ }^{104}$ http://eresources.nlb.gov.sg/newspapers/Digitised/Article/straitstimes19300228-

1.2.6.aspx?q=Institute+medical+research + in + malaya\&page $=1 \&$ sort=relevance\&token=malaya\%2cin\%2cresear ch\%2cmedical\%2cinstitute\&sessionid=f811bca2c7cf425e8ba7ce7e34f44f76

${ }^{105}$ http://eresources.nlb.gov.sg/newspapers/Digitised/Article/singfreepressb19401007-

1.2.17.aspx?q=Institute+medical+research+in+malaya\&page=7\&sort=relevance\&token=malaya\%2cin\%2cresea rch\%2cmedical\%2cinstitute\&sessionid=095b0acac55b485583783a2984c32f3a

${ }^{106}$ http://eresources.nlb.gov.sg/newspapers/Digitised/Article/straitstimes19290327-

1.2.54.aspx?q=Institute+medical+research+in+malaya\&page=4\&sort=relevance\&token=malaya\%2cin\%2cresea rch\%2cmedical\%2cinstitute\&sessionid=fffe7e0dd7b1495f87118fd85e038f21 